\title{
WPŁYW STARZENIA SIĘ SPOŁECZEŃSTWA NA \\ ORGANIZACJĘ SYSTEMU OCHRONY ZDROWIA W POLSCE
}

\author{
Małgorzata Jeziorska \\ dr inż., Katedra Ubezpieczeń, \\ Wydział Ekonomiczno-Socjologiczny, \\ Uniwersytet Łódzki
}

\section{Wprowadzenie}

Art. 68 Konstytucji Rzeczpospolitej Polskiej gwarantuje obywatelom prawo do ochrony zdrowia. Obecna sytuacja ekonomiczno-prawna nie pozwala niestety w pełni korzystać z tej gwarancji. Niedofinansowanie publicznego systemu ochrony zdrowia, problemy z dystrybucją wprowadzanych do systemu środków, niedoskonała priorytetyzacja oraz bariery przy korzystaniu z procedur medycznych w ramach finansowania własnego skutecznie utrudniają obywatelom proces diagnostyki i leczenia. Prognoza liczby ludności na kolejne dekady wskazuje, że proces starzenia się społeczeństwa polskiego będzie się pogłębiał. Zaskutkuje to zwiększonym zapotrzebowaniem na kosztowne procedury medyczne dedykowane osobom w wieku poprodukcyjnym. Aby system ochrony zdrowia w Polsce mógł sprostać stawianym przed nim zadaniom, konieczna jest jego reorganizacja. $Z$ uwagi na i tak duży już udział środków prywatnych finansujących procedury medyczne i farmaceutyki słusznym byłoby uregulowanie, dotychczas nieujętego w ścisłe ramy prawne strumienia.

W pracy skupiono się na analizie wpływu wydłużającego się czasu trwania życia w Polsce na funkcjonowanie systemu opieki zdrowotnej. W analizach wykorzystane zostały dane i opracowania Eurostatu i GUS-u. 


\section{Sytuacja demograficzna społeczeństwa Polski}

Ostatnie trzy dekady przyniosły Polsce spowolnienie rozwoju demograficznego. Widoczne stały się zmiany w strukturze wieku mieszkańców. Wydłużanie się czasu trwania życia, niski poziom dzietności oraz zwiększona emigracja młodych osób zaowocowały starzeniem się ludności Polski [GUS 2014a: 2].

Polska, na tle innych krajów Unii Europejskiej (UE), jeszcze wciąż postrzegana jest jako kraj demograficznie młody. Na poniższym rysunku zaprezentowana została struktura wiekowa ludności Polski i 28 krajów UE dla roku 2015.
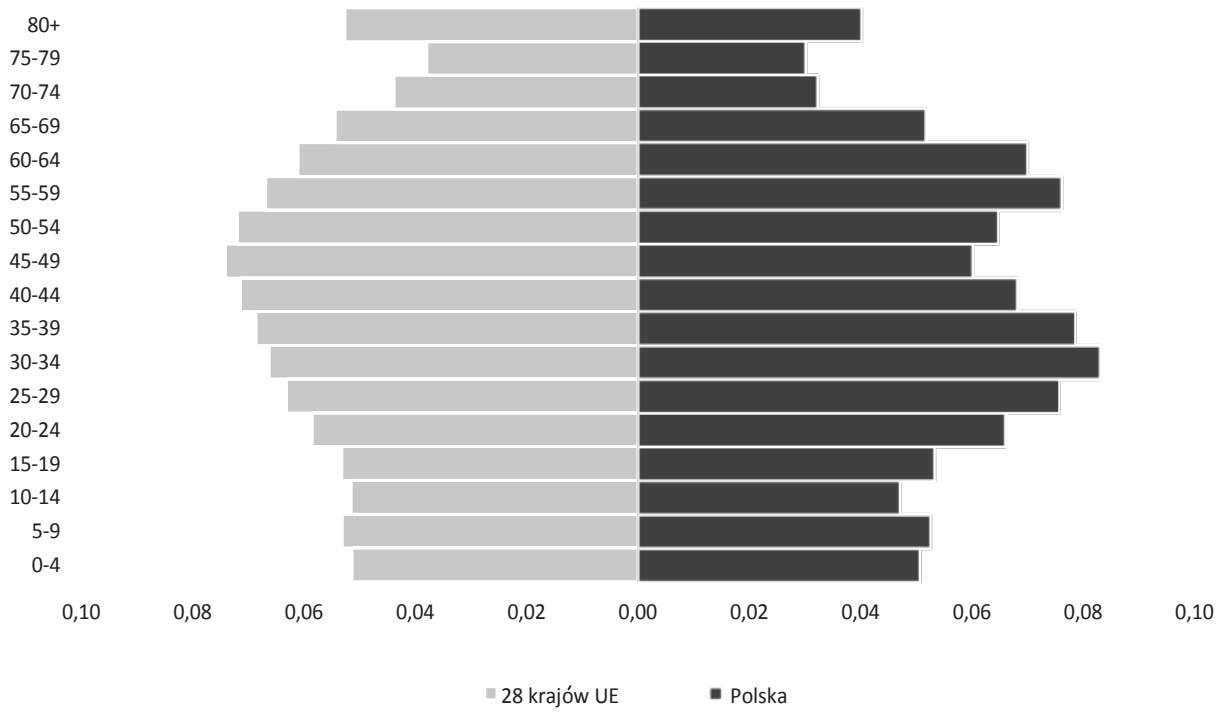

Rysunek 1. Piramida wieku - populacja Polski i krajów UE, rok 2015

Źródło: opracowanie własne na podstawie danych Eurostatu.

W trakcie ostatniego ćwierćwiecza mediana wieku ludności Polski wzrosła o 7 lat (z 32 lat dla roku 1990 do 39 dla roku 2015). Tendencja wzrostowa jest zgodna $\mathrm{z}$ sytuacją obserwowaną w całej UE. We wskazanym okresie wiek środkowy dla populacji UE (27 krajów) wzrósł z 35 do 41 lat. Poniższe rysunki prezentują zmiany struktury wiekowej społeczeństw Polski i UE (27 krajów) dla dwóch punktów czasowych - roku 1990 i 2015. 

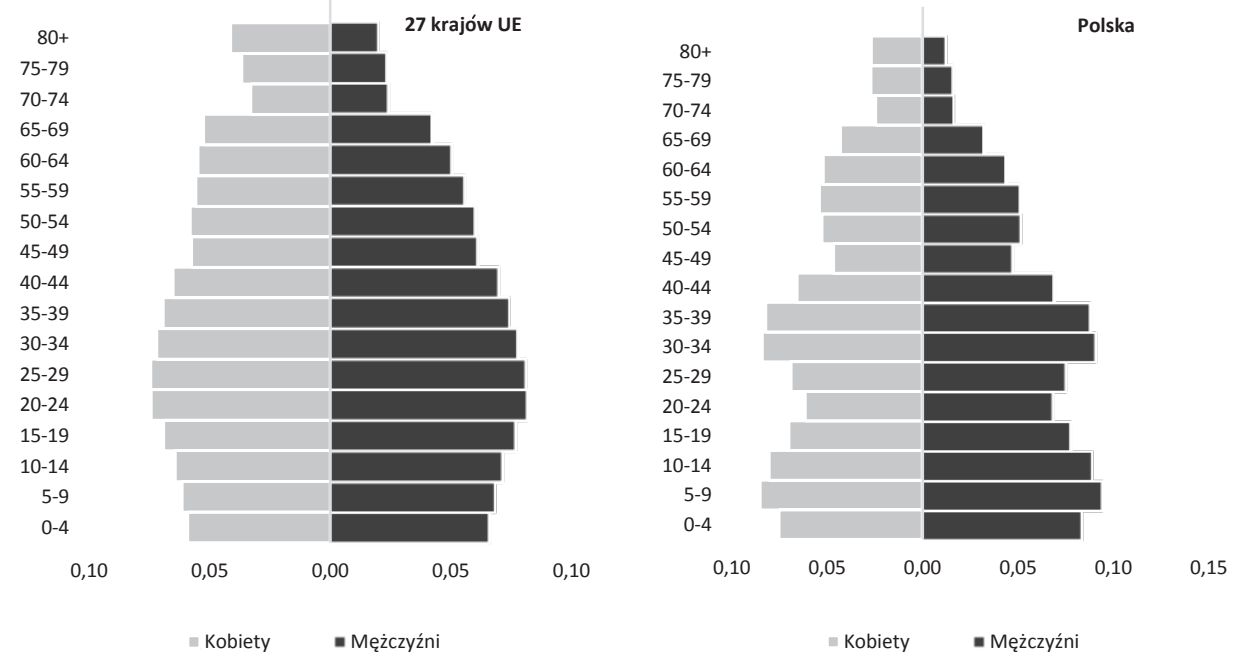

Rysunek 2a. Piramida wieku w podziale na płeć - populacja Polski i 27 krajów UE (bez Chorwacji), rok 1990 Źródło: opracowanie własne na podstawie danych Eurostatu.
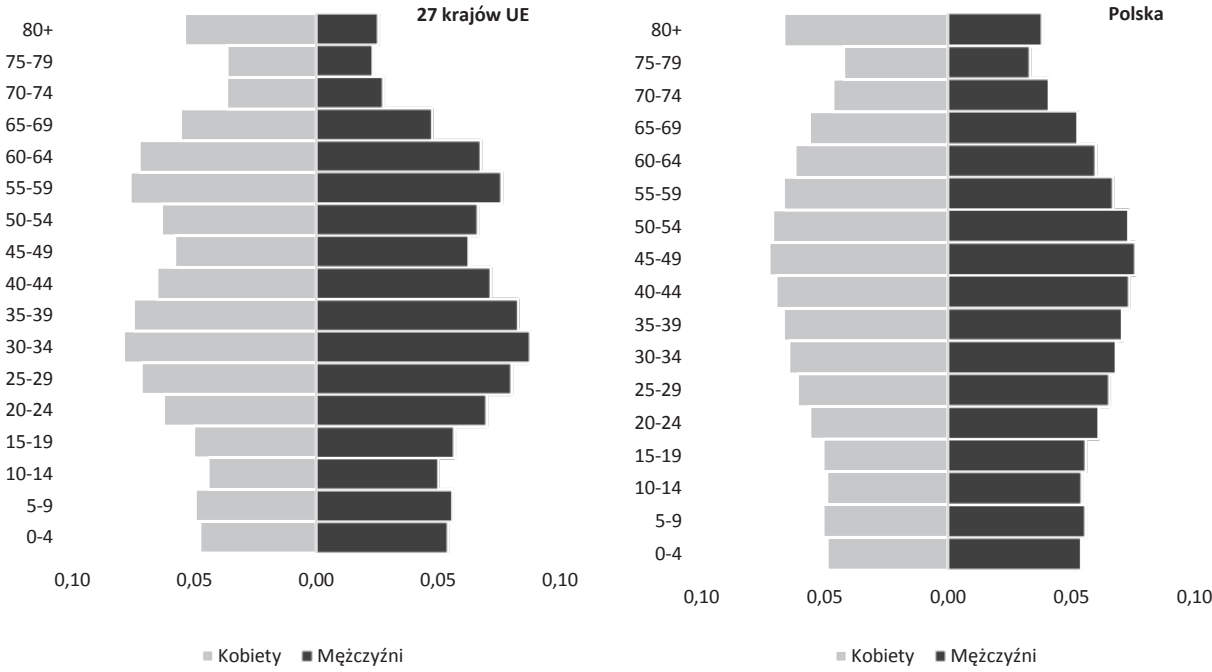

Rysunek 2b. Piramida wieku w podziale płeć - populacja Polski i 27 krajów UE (bez Chorwacji), rok 2015 Źródło: opracowanie własne na podstawie danych Eurostatu. 
Innym miernikiem obrazującym stopień zawansowania starzenia się populacji jest udział ludności w wieku 65 lat i więcej w populacji ogółem. Pomiędzy 2005 a 2015 rokiem wspomniany wskaźnik wzrósł o 5 p.p. (zmiana na tym samym poziomie obserwowana była dla Polski i 27 krajów UE).

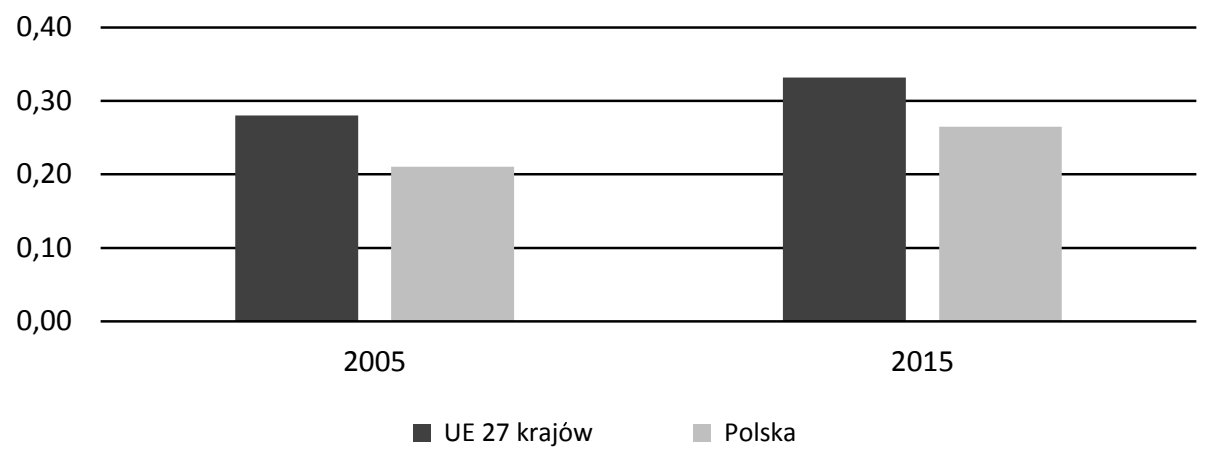

Rysunek 3. Procentowy udział osób w wieku 65 lat i więcej w łącznej liczbie ludności - Polska vs. kraje UE, lata 2005, 2015

Źródło: opracowanie własne na podstawie danych Eurostatu.

W 2014 roku Polska zaliczała się do państw o najniższym udziale liczby osób w wieku 65 i więcej do liczby osób w wieku produkcyjnym (19-64 lat). Szacuje się jednak, że już w 2050 roku wskaźnik przewyższy średnią dla całej UE. Po 2020 roku udział osób w wieku 65 lat i więcej w strukturze ludności Polski w wieku produkcyjnym przekroczy $30 \%$, zaś po 2080 roku $-65 \%$.

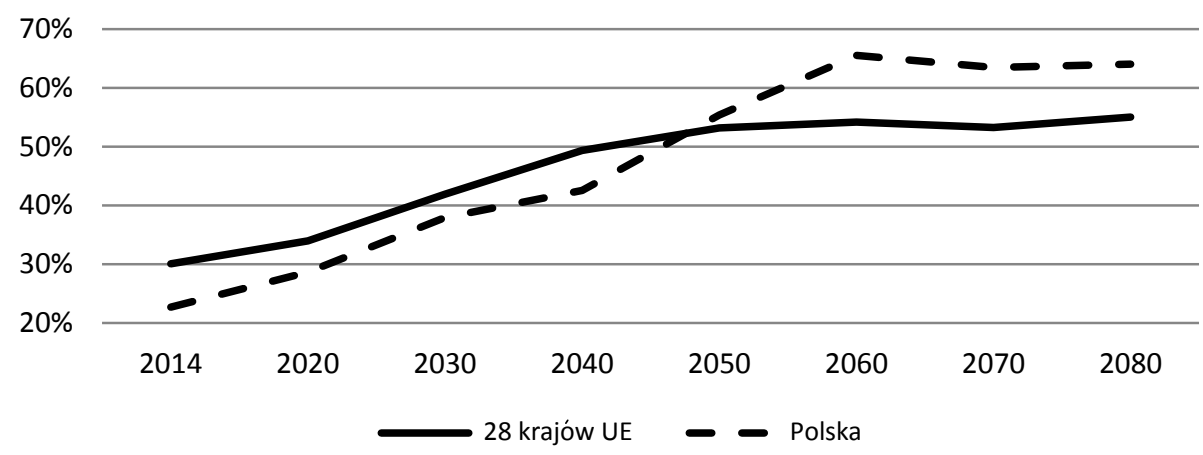

Rysunek 4. Zmiana procentowego udziału liczby osób w wielu poprodukcyjnym (65 lat i więcej) w łącznej liczbie osób w wieku 19-64 - Polska vs. kraje UE, lata 2014-2080

Źródło: opracowanie własne na podstawie danych Eurostatu. 
Rozwój ekonomiczny, zdrowszy styl życia i postęp medycyny zaskutkowały wyższą oczekiwaną długością życia.

$\mathrm{Na}$ rysunku 5 zaprezentowano zmianę oczekiwanej długości trwania życia 65-latka - dane za lata 2004-2013.

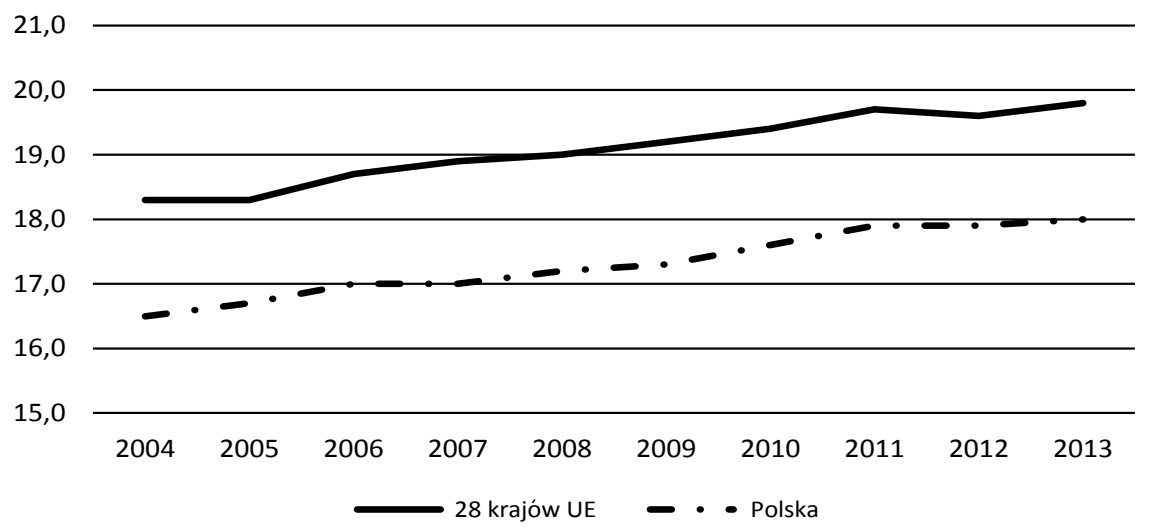

Rysunek 5. Oczekiwana długość trwania życia 65-latka - Polska vs. kraje UE Źródło: opracowanie własne na podstawie danych Eurostatu.

Podkreślić należy jednak fakt, że wzrost oczekiwanej długości życia nie idzie w parze z oczekiwaną liczbą lat życia w zdrowiu (HLY). W przypadku wskaźnika HLY tendencja wzrostowa nie jest już widoczna. Na poniższym rysunku zaprezentowane zostały wskaźniki HLY dla 65-letnich mieszkańców Polski i ich rówieśników z krajów UE w latach 2007-2013.

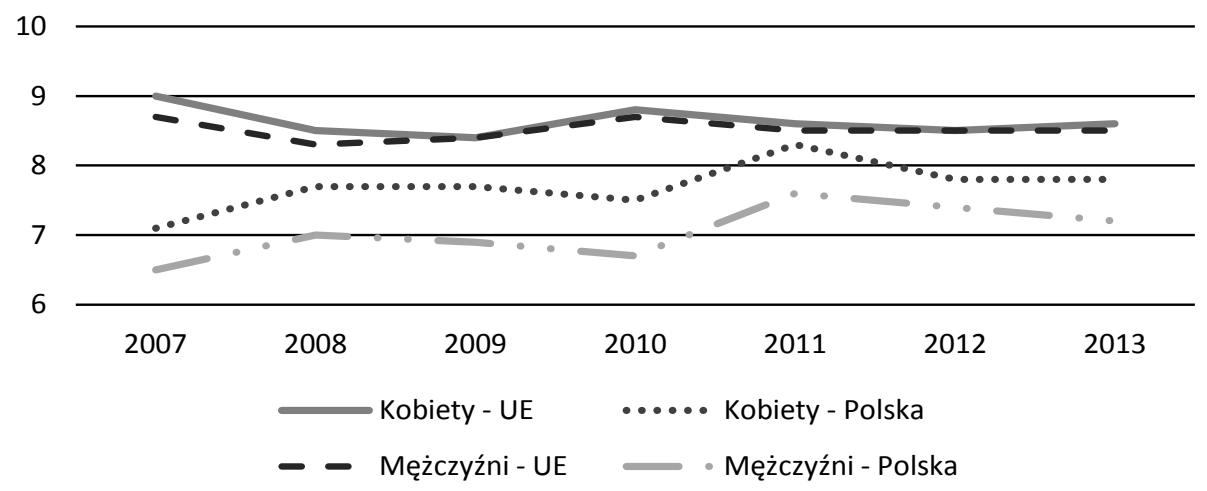

Rysunek 6. Przeciętna długość trwania życia w zdrowiu osoby w wieku 65 lat - Polska vs. kraje UE, lata 2007-2013 Źródło: opracowanie własne na podstawie danych Eurostatu. 
Utrzymanie się takiej tendencji w długiej perspektywie będzie prowadzić do wzrostu potrzeb w zakresie opieki zdrowotnej oraz środków na realizację programów ochrony zdrowia.

\section{Efektywność systemu ochrony zdrowia wobec zmian demograficznych społeczeństwa w Polsce}

Postępujący proces starzenia się społeczeństwa oraz rozwój technologii i wiedzy medycznej kreują większy popyt na świadczenia zdrowotne [Rozkrut 2013: 33-34]. Aby sprostać wyzwaniom jakie stawiają przed społeczeństwem zmiany demograficzne związane ze starzeniem się populacji podejmować należy szereg działań na rzecz rozwoju tzw. „silver economy". Skupić należy się na rozwoju medycyny geriatrycznej, opieki długookresowej nad osobami w podeszłym wieku, zwiększeniu możliwości dostępu do odpowiedniej jakości usług zdrowotnych, nowoczesnej rehabilitacji i usług opiekuńczych, intensyfikacji wszelkich form aktywności ludzi starszych, wykorzystania ich potencjału, zapobieganiu wykluczeniu społecznemu [Waligórska i Kostrzewa 2014: 25].

Z przygotowywanych przez Światową Organizację Zdrowia raportów wynika, że poziom nakładów na służbę zdrowia pozostaje w bezpośrednim związku z poziomem zdrowia społeczeństw.

Według metodologii SHA2011 wydatki bieżące na ochronę zdrowia w 2014 roku wyniosły 108,7 mld zł i były wyższe niż w 2013 roku o około 1,9 mld zł. Nakłady te stanowiły 6,33\% PKB (6,45\% w 2013). Bieżące wydatki publiczne poniesione na zdrowie i ochronę zdrowia wynosiły w 2014 roku 77,2 mld zł i stanowiły 4,49\% PKB (4,58\% w 2013), natomiast bieżące wydatki prywatne wyniosły 31,5 mld zł i stanowiły $1,83 \%$ PKB (1,87\% w 2013) [GUS 2016b: 1].

Warto zwrócić uwagę, że intensywność korzystania z usług medycznych zmienia się wraz z wiekiem. Najliczniej zbiorowość leczonych osób reprezentują dzieci do 4 roku życia i pacjenci w wieku 50+ [Koehne i in. 2011: 84]. Średnie wydatki NFZ na jednego obywatela również różnią się znacząco w zależności od grupy wiekowej. Dla grupy 65+ średnia jest niemal trzy razy wyższa od tej dla młodszej części populacji. W obliczu zmian demograficznych w społeczeństwie Polski, zaskutkuje to niewątpliwie zwiększeniem wydatków na świadczenia medyczne. 


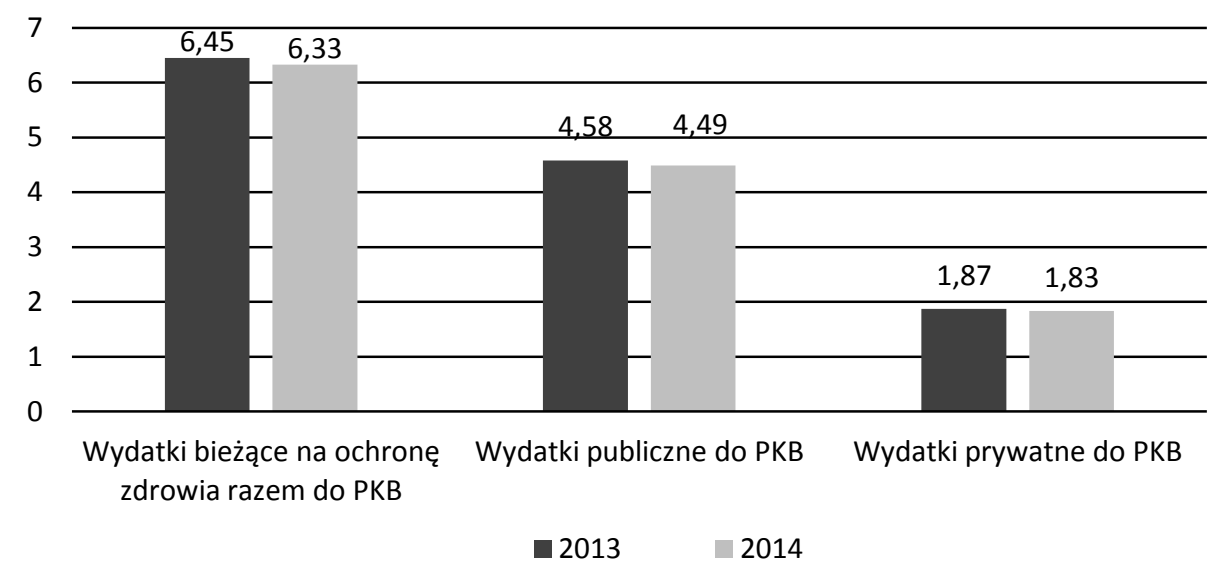

Rysunek 7. Udział wydatków bieżących na ochronę zdrowia w PKB (\%), lata 2013, 2014 Źródło: opracowanie własne na podstawie danych GUS [2016b: 1].

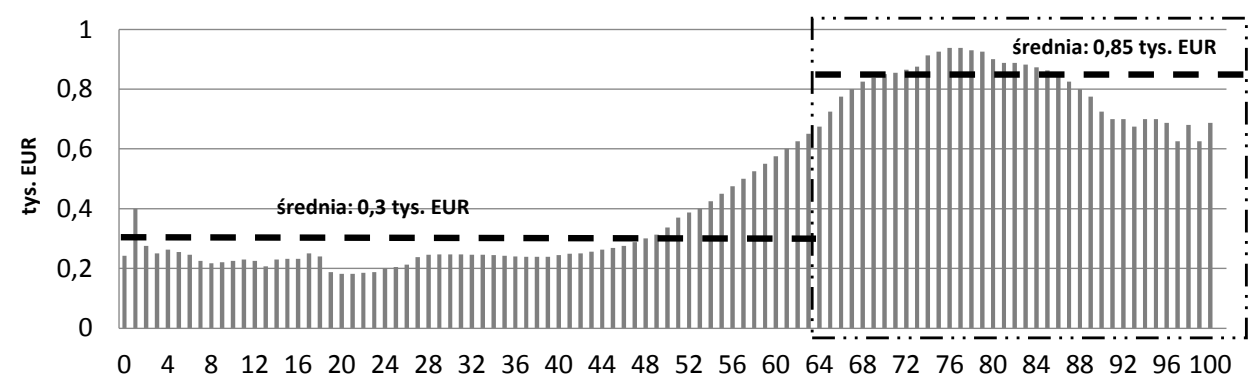

Rysunek 8. Profil wydatków NFZ na świadczenia opieki zdrowotnej w Polsce na mieszkańca w zależności od wieku, rok 2011 Źródło: Rozkrut [2013: 39].

Należy podkreślić, że badania dotyczące subiektywnej oceny zdrowia Polaków wskazują, że udział osób starszych, które oceniają swój stan jako zły lub bardzo zły jest wysoki (21\% badanej populacji w wieku 60-69, 35\% osób w wieku 70-79 i aż 50\% osób z kategorii 80+) [GUS 2016a: 13].

Nie tylko wielkość nakładów na ochronę zdrowia ma znaczenie. Stabilność i efektywność systemu opieki zdrowotnej, a tym samym realność ochrony, może zostać naruszona poprzez nieprecyzyjną alokację środków finansowych. Przyczynić się do tego może nadreprezentacja specjalistycznych usług medycznych w stosunku do rzeczywistych potrzeb, nakładanie się na siebie systemów i programów oraz niekontrolowana komercjalizacja usług zdrowotnych w warunkach nieuregulowanego systemu usług me- 
dycznych (Stańdo-Górska 2012: 78). Zmiany we wskazanych obszarach prawdopodobnie przyczyniłyby się do poprawy efektywności alokacji środków finansowych wydatkowanych na ochronę zdrowia.

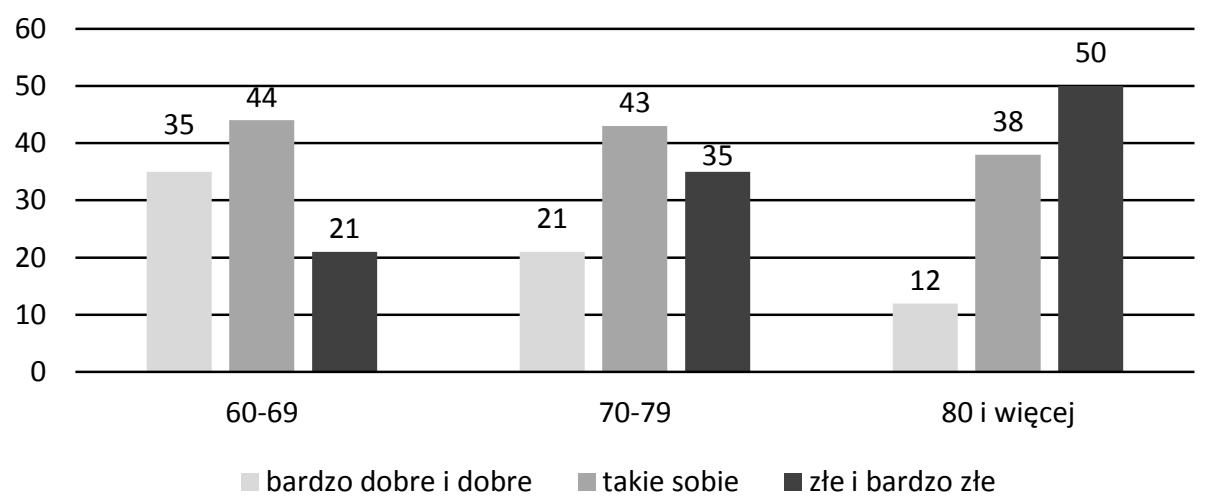

Rysunek 9. Samoocena stanu zdrowia osób w wieku 60 lat i więcej, rok 2014

Źródło: GUS [2016a: 13].

W raporcie przygotowanym przez Health Consumer Powerhouse, prezentującym Europejski Konsumencki Indeks Zdrowia (EHCI) za rok 2015, Polska zajęła 34 miejsce na 35 krajów biorących udział w badaniu (plasowała się za Albanią, wyprzedzając jedynie Czarnogórę). Na tak niską pozycję złożyły się m.in. niebezpiecznie długie okresy oczekiwania na leczenie raka, zakażenia wewnątrzszpitalne, niesprawiedliwości w służbie zdrowia. Tak niska nota wskazuje na pilną potrzebę zmian w systemie opieki zdrowotnej w Polsce.

Jak wskazują wyniki badania przeprowadzonego przez GUS, opóźnienia z powodu długiego okresu oczekiwania sygnalizowało prawie $25 \%$ osób potrzebujących opieki zdrowotnej w roku 2014 [GUS 2016c: 139].

Wobec niewydolności publicznego systemu opieki zdrowotnej Polacy zmuszeni są do korzystania $\mathrm{z}$ usług medycznych pokrywanych ze środków własnych. Niestety tylko niewielki odsetek z nich to wydatki na uregulowane prawnie instrumenty tj. dodatkowe ubezpieczenia zdrowotne i abonamenty medyczne. Gospodarstwa domowe wydatkują przede wszystkim na leki i artykuły medyczne oraz ambulatoryjną opiekę zdrowotną (98\%).

Jako główne przyczyny korzystania $\mathrm{z}$ usług medycznych i stomatologicznych poza systemem publicznym wskazywane są zbyt odległe terminy wizyt w podmiotach mających kontrakty w NFZ, lepsi specjaliści, wyposażenie w sprzęt i materiały medyczne oraz niefinansowanie usług. 


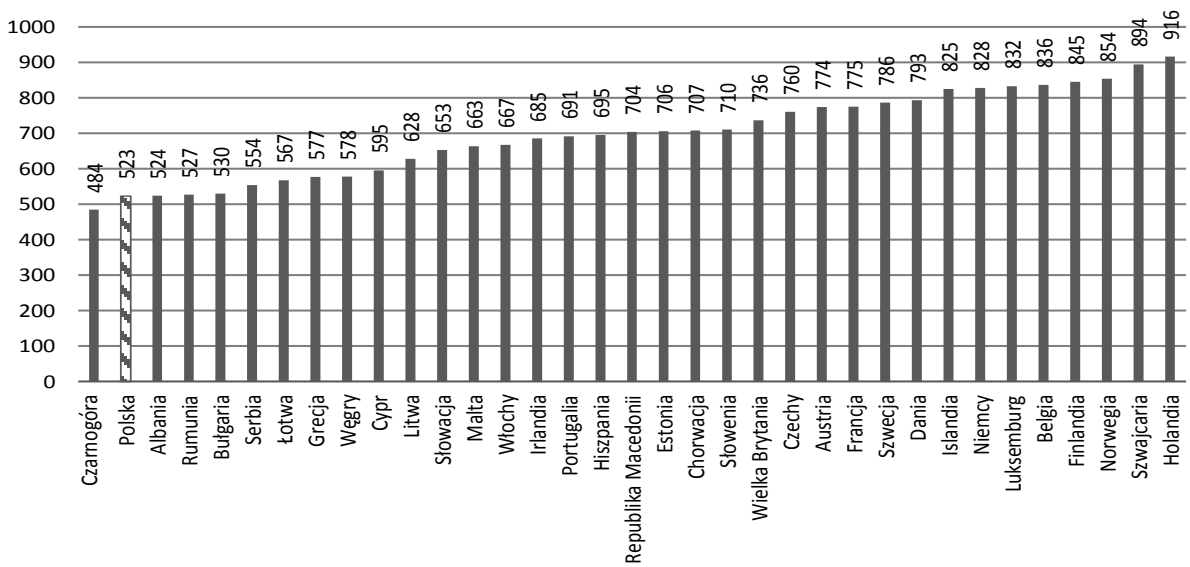

Rysunek 10. Europejski Konsumencki Indeks Zdrowia, rok 2015 Źródło: Health Consumer Powerhouse Ltd [2016].

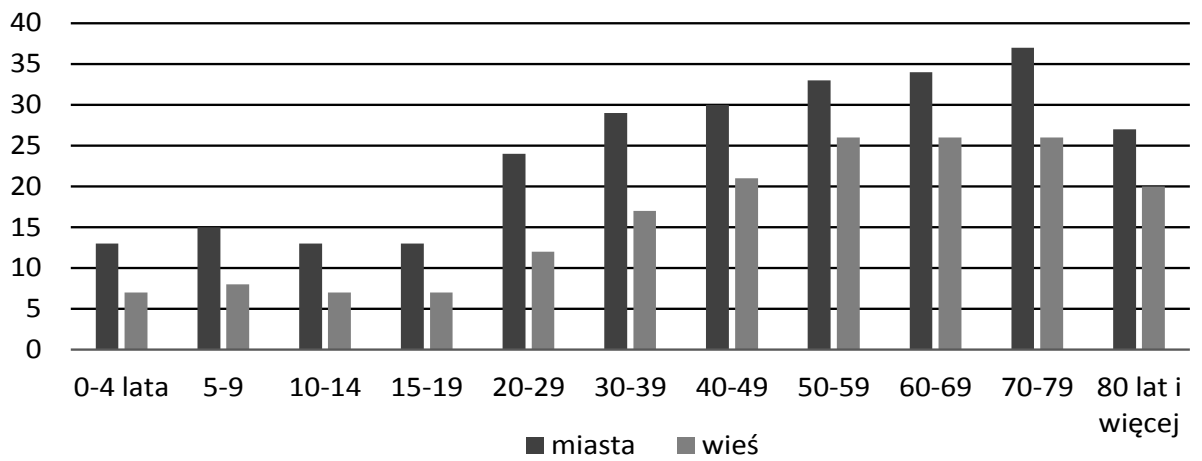

Rysunek 11. Opóźnienia w dostępie do opieki zdrowotnej z powodu długiego czasu oczekiwania wg grup wieku (w odsetkach osób potrzebujących), rok 2014 Źródło: GUS [2016c: 139].

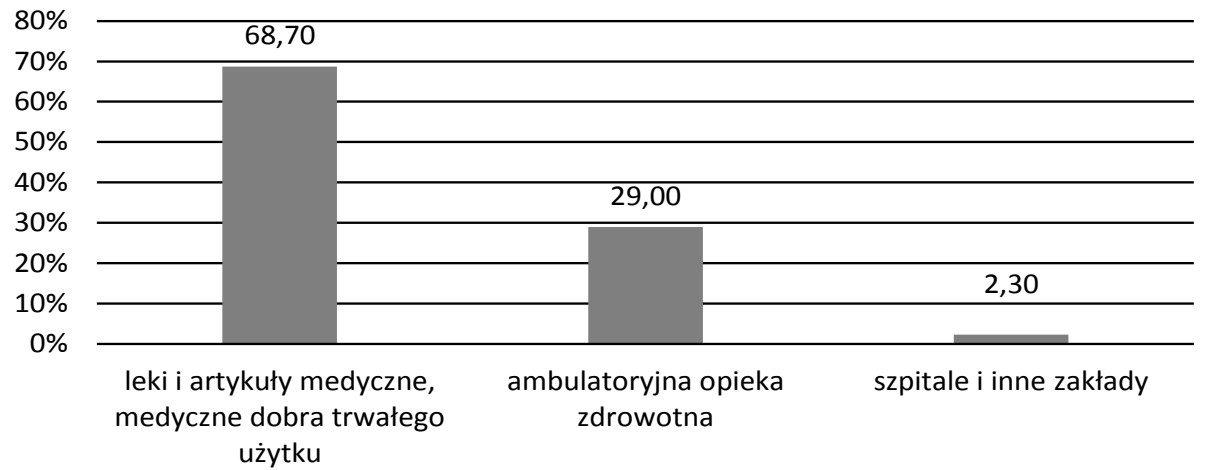

Rysunek 12. Struktura wydatków gospodarstw domowych na ochronę zdrowia, rok 2013 Źródło: GUS [2014b: 6]. 
zbyt odległe terminy wizyt w podmiotach mających kontrakty w NFZ lepsi specjaliści (lekarze) brak lekarza odpowiedniej specjalności w podmiotach mających kontrkaty z NFZ niefinansowanie usług przez NFZ lepsze wyposażenie w sprzęt i materisły medyczne inne przyczyny

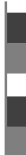

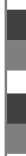

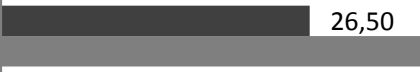

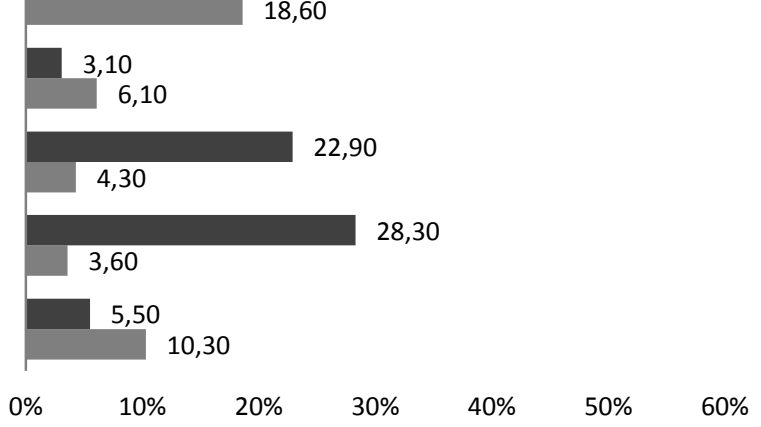

- usługi stomatologiczne usługi medyczne

Rysunek 13. Przyczyny korzystania z usług medycznych i stomatologicznych niefinansowanych przez NFZ, rok 2013

Źródło: GUS [2014b: 5].

Jak wskazują statystyki $\mathrm{z}$ roku na rok rośnie udział gospodarstw domowych korzystających $\mathrm{z}$ placówek opieki zdrowotnej w ramach finansowania własnego (z 38,6\% dla roku 2000 do 50,6\% dla roku 2013). Zwiększył się też odsetek domostw korzystających z opieki medycznej finansowanej ze środków publicznych. Wzrost ten nie jest jednak aż tak bardzo dynamiczny (z 86,4\% dla 2000 roku do 92,4\% dla roku 2013). Widoczny jest również przyrost gospodarstw wykorzystujących pakiety medyczne i abonamenty.

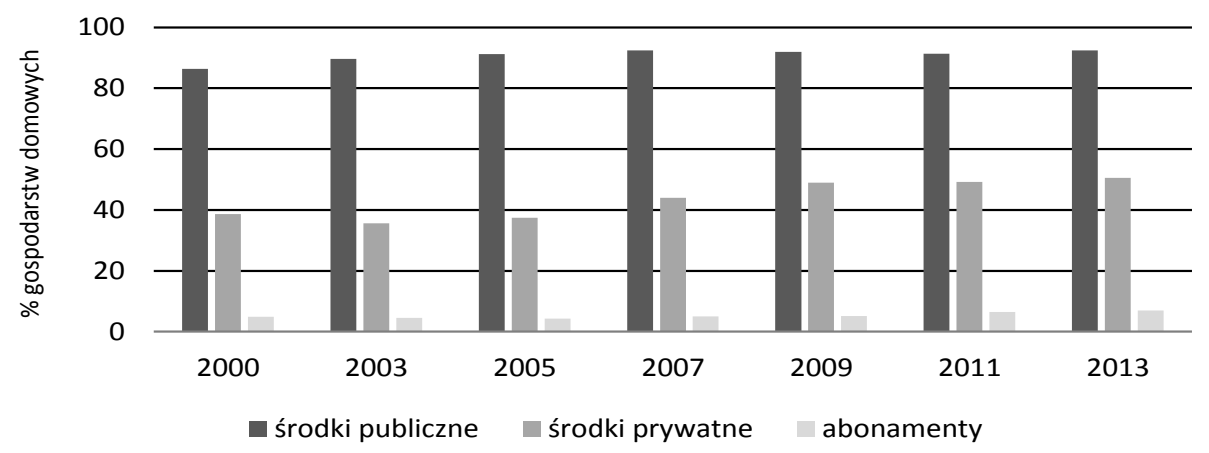

Rysunek 14. Odsetek gospodarstw domowych korzystających z placówek opieki zdrowotnej według źródła finansowania usług, rok 2013

Źródło: Czapiński i Panek [2014: 126]. 
Optymalna alokacja środków trafiających do systemu opieki zdrowotnej w skali kraju nie może zostać osiągnięta bez precyzyjnego uregulowania rynku usług medycznych przez państwo [Stańdo-Górska 2012: 77]. Brak regulacji prawnych skutkuje bardzo powolnym rozwojem rynku dodatkowych ubezpieczeń zdrowotnych. W porównaniu z innymi krajami UE, Polska ma niekorzystną strukturę prywatnych wydatków na ochronę zdrowia. Obecnie zdecydowana większość świadczeń opieki zdrowotnej pokrywanych ze środków prywatnych jest finansowana na zasadzie opłaty za poszczególne świadczenia. Współpłacenie Polaków z własnej kieszeni wynosi ok. 33\% wszystkich wydatków na zdrowie i plasuje Polskę nieco powyżej średniej unijnej [Fal 2013: 48-49].

Aby w sposób efektywny móc stawić czoła procesowi starzenia się społeczeństwa polskiego i być w stanie w pełni wykorzystać wszystkie możliwości jakie daje rozwój medycyny niezbędne jest zwiększenie wydatków na ochronę zdrowia i lepsza priorytetyzacja zadań. Niewątpliwym bowiem jest fakt, że wyższe nakłady właściwie ukierunkowane na diagnostykę i leczenie istotnie wpływają na wydłużenie okresu życia w zdrowiu. Wzrost nakładów na ochronę zdrowia realizowany mógłby być oczywiście poprzez podniesienie składek na obowiązkowe ubezpieczenie zdrowotne albo redukcję innych wydatków finansowanych z budżetu państwa, ale nie byłyby to rozwiązania optymalne [PIU, E\&Y 2013: 10]. Odciążenie publicznego systemu ochrony zdrowia zapewnić można byłoby poprzez wprowadzenie współfinansowania świadczeń zdrowotnych ze środków prywatnych za pośrednictwem uregulowanego prawnie instrumentu dodatkowych ubezpieczeń zdrowotnych.

\section{Podsumowanie}

Postępujące zmiany demograficzne w społeczeństwie i związany z nimi zwiększający się popyt na świadczenia medyczne wymuszają zmiany w finansowaniu systemu ochrony zdrowia w Polsce. Funkcjonujący system publicznego ubezpieczenia zdrowotnego, pomimo wzrostu nakładów finansowych na zabezpieczenie świadczeń zdrowotnych, wciąż nie jest wystarczająco efektywny. Liczne problemy, z którymi się boryka dotykają bezpośrednio pacjentów. Pomimo podwojenia poziomu nakładów na opiekę medyczną w ostatniej dekadzie, Polacy nie oceniają systemu ochrony zdrowia jako skutecznie zaspokającego ich potrzeby. Obywatele, aby w realnie krótkim czasie uzyskać potrzebną pomoc medyczną, zmuszeni są do współfinansowania leczenia ze środków prywatnych. Z uwagi 
na to, że obecnie większość środków własnych obywateli, wydatkowanych na zaspokojenie potrzeb związanych $\mathrm{z}$ ochroną zdrowia, procedowanych jest $\mathrm{w}$ sposób niezinstytucjonalizowany, trudno prowadzić efektywną politykę wspierającą publiczny system ochrony zdrowia. Wspieranie powszechności dobrowolnych ubezpieczeń zdrowotnych, skoordynowanych z systemem publicznym, pomogłoby zapewne w stworzeniu bardziej skutecznych mechanizmów opieki zdrowotnej dla obywateli Polski.

\section{Bibliografia}

Baza danych Eurostat, strona internetowa: http://ec.europa.eu/eurostat/web.

Czapiński J., Panek T. (2014), Diagnoza społeczna 2013. Warunki i jakość życia Polaków,

Ministerstwo Pracy i Polityki Społecznej, Centrum Rozwoju Zasobów Ludzkich, Warszawa.

Eurostat (2015), Employment, Social Affairs \& Inclusion Eurostat Demography Report, Publications Office of the European Union, Luxembourg.

Fal D. (2013), Korzyści z rozwoju rynku dodatkowych ubezpieczeń zdrowotnych w Polsce, „Wiadomości Ubezpieczeniowe”, nr 4.

Golinowska S. (red.) (2012), Zarys systemu ochrony zdrowia Polska 2012, NFZ, Warszawa. GUS (2014a), Sytuacja demograficzna osób starszych i konsekwencje starzenia się ludności Polski w świetle prognozy na lata 2014-2050.

GUS (2014b), Ochrona zdrowia w gospodarstwach domowych w 2013 r.

GUS (2015), Podstawowe informacje o rozwoju demograficznym Polski do 2014 r.

GUS (2016a), Notatka przygotowana na posiedzenie Sejmowej Komisji Polityki Senioralnej dotyczące "Informacji Ministra Zdrowia na temat wpływu zmian demograficznych i starzenia się społeczeństwa na organizację systemu ochrony zdrowia i Narodowy Program Zdrowia".

GUS (2016b), Narodowy rachunek zdrowia w 2014 r.

GUS (2016c), Stan zdrowia ludności w 2014 r.

Health Consumer Powerhouse Ltd (2016), Euro Health Consumer Index 2015, https:// piu.org.pl/europejski-konsumencki-indeks-zdrowia-2015-po-polsku.

Jeziorska M. (2016), Dodatkowe ubezpieczenia zdrowotne jako instrument mogący usprawnić funkcjonowanie systemu ochrony zdrowia w Polsce, "Acta Universitatis Lodziensis. Folia Oeconomica", nr 318.

Koehne N., Lednicki B., Piekarzewska M., Wieczorkowski R., Zajenkowska-Kozłowska A. (2011), Stan zdrowia ludności Polski w 2009 r., GUS, Warszawa.

Łanda K. (2013), Dostępność świadczeń gwarantowanych w Polsce na podstawie Barometru Fundacji Watch Health Care, „Wiadomości Ubezpieczeniowe”, nr 4. 
Marciniak G. (red.) (2005), Stan zdrowia ludności Polski w 2004 r., GUS, Warszawa.

Nawrolska I. (2011) Polski system ochrony zdrowia. Potrzeba redefiniowania priorytetów,

„Zeszyty Naukowe Polskiego Towarzystwa Ekonomicznego", nr 11.

PIU, E\&Y (2013), Rola i funkcja dodatkowych ubezpieczeń zdrowotnych we współczesnych systemach ochrony zdrowia - analiza i rekomendacje dla Polski, PIU, Warszawa.

Rozkrut M. (2013), Analiza możliwości zaspokojenia rosnących potrzeb zdrowotnych. Prognozy rozwoju rynku dodatkowych ubezpieczeń zdrowotnych w Polsce, „Wiadomości Ubezpieczeniowe", nr 4.

Ryć K., Skrzypczak. Z (2005), Publiczne i prywatne wydatki na ochronę zdrowia w Polsce. Ile nas kosztuje ochrona zdrowia? , „Problemy zarządzania”, nr 10.

Stańdo-Górska H. (2012), Kształtowanie wydatków na opiekę zdrowotna jako problem społeczno-ekonomiczny, "Nierówności społeczne a wzrost gospodarczy", nr 26.

Świtała M. (2009), Samoocena stanu zdrowia i jej wpływ na zachowania konsumentów w starszym wieku , "Gerontologia Polska", t. 17, nr 3.

Waligórska M., Kostrzewa Z. (2014), Prognoza ludności na lata 2014-2050, GUS, Warszawa. Żyra M. (2014), Zdrowie i ochrona zdrowia w 2013 r., GUS, Warszawa.

\section{WPŁYW STARZENIA SIĘ SPOŁECZEŃSTWA NA ORGANIZACJĘ SYSTEMU OCHRONY ZDROWIA W POLSCE}

Prognoza liczby ludności Polski na kolejne dekady wskazuje na utrwalenie trendu starzenia się społeczeństwa. Przewidywane zmiany demograficzne, przy utrzymaniu dotychczasowych zasad funkcjonowania systemu ubezpieczeń zdrowotnych, mogą mieć daleko idące konsekwencje dla zapewnienia realności ochrony ubezpieczeniowej w Polsce. W niniejszym artykule poruszono tematykę wpływu zmian demograficznych w społeczeństwie na zwiększanie się popytu na świadczenia w ramach systemu opieki zdrowotnej. Źródłem informacji ilościowych wykorzystywanych w pracy były opracowania GUS-u i Eurostatu.

Słowa kluczowe: proces starzenia się społeczeństwa, dobrowolne ubezpieczenia zdrowotne, oczekiwana długość życia, wydatki na ochronę zdrowia.

\section{THE INFLUENCE OF DEMOGRAPHIC CHANGES ON FUNCTIONING OF THE HEALTHCARE SYSTEM IN POLAND}

Projection prepared by Central Statistical Office indicates that the process of polish society ageing will progress rapidly. Expected demographic changes may cause that the public healthcare system in Poland will be inefficient. This paper focuses on the dependence between aforementioned changes and increasing 
demand for health services within polish healthcare system. The data used come from Central Statistical Office of Poland and Eurostat.

Keywords: ageing of the population, non-compulsory private health insurance, life expectancy, health care expenditure. 